\title{
The Perceived Value in Ecotourism Related to Satisfaction and Loyalty: a Study from Costa Rica
}

\author{
Mauricio Carvache-Franco ${ }^{A}$, Allan Perez-Orozco ${ }^{B}$, Orly Carvache-Franco ${ }^{C}$, \\ Ana Gabriela Víquez-Paniagua ${ }^{B}$, Wilmer Carvache-Franco ${ }^{D^{*}}$ \\ Received: February 04, 2020 | Revised: September 09, 2020 | Accepted: September 11, 2020 \\ doi: 10.5937/gp24-25082
}

\begin{abstract}
Ecotourism allows activities in contact with nature in protected natural areas to contribute to environmental care. This study seeks to establish the dimensions of perceived value in ecotourism and analyze its relationship with satisfaction and loyalty. It was an in situ research carried out in two protected areas of Costa Rica: Arenal National Park and Caño Negro National Wildlife Refuge. The sample consisted of 310 surveys for domestic and foreign tourists. The data were interpreted through a factorial analysis to identify the dimensions that make up the perceived value. Also, Spearman's correlation technique and the stepwise multiple regression method were used to find the relationships among the variables. The findings show that there are three dimensions of perceived value: economic-functional, emotional, and social. Overall satisfaction and loyalty had a high average score, and the dimensions found are significantly and positively related to overall satisfaction. The "economic-functional value" dimension has a greater influence on overall satisfaction, and the "emotional value" dimension is the most significant predictor of the intentions to return, recommend, and say positive things about the ecotourism destination.
\end{abstract}

Keywords: ecotourism; perceived value; satisfaction; loyalty; Costa Rica

\section{Introduction}

Natural resources are one of the main attractions exploited by tourist activity; however, the incessant increase in the currents of national and international tourists who visit different destinations each year can lead to great changes in ecosystems (Si-Shyun, 2018). Ecotourism grows three times faster than tourism in general (Hultman et al., 2015). In the ecotourism modality, tourists have diverse reasons to visit different attractions and destinations related to nature (Chikuta et al., 2017). Their ecotourism preferences can be varied, including nature, culture, farm, wildlife, and adventure (Björk, 2007; Honey, 2008). Specifically, community ecotourism has focused not only on the conservation of the environment but also on the preservation of the culture to improve the well-being of the local population (Jones, 2005; Liu et al., 2014; Reimer \& Walter, 2013). For rural communities, ecotourism could become a gateway for economic development (Ketema, 2015). In these circumstances, to sustain the tourist activity, preventive or remedial measures must be taken

\footnotetext{
A Universidad Espíritu Santo-Ecuador, Km. 2,5 Vía a Samborondón, Samborondón, Ecuador, E- mail, mauricio2714@hotmail.com, https://orcid.org/0000-0003-3639-9263

B Instituto Tecnológico de Costa Rica, Escuela de Administración de Empresas, Campus San Carlos, P.O. Box 159-7050, Alajuela, Costa Rica, e-mail: aperez@itcr.ac.cr; aviquez@itcr.ac.cr

c Universidad Católica de Santiago de Guayaquil. Facultad de Especialidades Empresariales. Km 1.5 Av. Carlos Julio Arosemena, Guayaquil, Ecuador, Email: orly.carvache@cu.ucsg.edu.ec, https://orcid.org/0000-0002-3108-9410

D Escuela Superior Politécnica del Litoral, ESPOL. Facultad de Ciencias Sociales y Humanísticas, Campus Gustavo Galindo Km 30.5 Vía Perimetral, P.O. Box 09-01-5863, Guayaquil, Ecuador, E- mail: wcarvach@espol.edu.ec, http://orcid.org/0000-0001-5420-1092

* Corresponding author: Wilmer Carvache-Franco; e-mail: wcarvach@espol.edu.ec
} 
to avoid the negative impact it may bring (Briassoulis \& Van Der, 2013; Tanti \& Raya, 2016).

In this regard, the destinations that base their tourism offer mainly on their natural resources have to face great challenges to maintain their sustainability. In this sense, there is an increase in the demand of tourists who are attracted to nature, giving greater value to the spaces perceived as responsible in ecological terms, and producing a permanent pressure on the environment of the place (Thapa \& Lee, 2017). That is why protected areas have to optimize the experience assuming the double role, that of providing enjoyment through recreational activities and maintaining the sustainability of their natural areas that are part of the tourist heritage of the place (Wolf et al., 2017; Thapa \& Lee, 2017). Ecotourism, green tourism or nature-oriented tourism is a segment that is reaching a growing popularity throughout the world. Therefore, each tourist destination receives more and more tourists who like contact with nature and are willing to comply with the protection rules of the natural area chosen to carry out leisure activities (Cheng \& Wu, 2015). Also, the studies on the perceived value of tourists who like contact with nature emphasize the importance of knowing how and to which destination attributes the tourist gives a greater value during their travel experience. This market segment has a collective appreciation, understanding and assessment of the existence of environmental problems in the world (Chiu et al., 2014; Mostafa, 2007).
In this context, Costa Rica is a country that receives tourist flows to carry out activities in nature. This ecotourism destination of international importance has a large number of protected natural areas, including the Arenal National Park and the Caño Negro National Wildlife Refuge. The Arenal National Park is home to the Arenal Volcano, an icon of the nature of this country. The Caño Negro National Wildlife Refuge hosts a large number of endangered species.

Although this important ecotourism destination has a large number of protected areas considered main attractions within ecotourism, so far, no empirical studies have been carried out on the perceived value related to this type of tourism in Costa Rica. This study adds to the scientific literature as it is one of the few inquiries that analyzes the perceived value in protected areas. In fact, to the best of our knowledge, there are no studies in the literature that analyze the dimensions of perceived value that influencesatisfaction and predict ecotourism loyalty.

Therefore, this research focuses on establishing the dimensions that make up the perceived value and analyzing its relationship with the satisfaction and loyalty in ecotourism. The research was carried out in two protected natural areas of Costa Rica: Arenal National Park and Caño Negro National Wildlife Refuge. The theoretical and empirical findings of this research may have implications in the management of protected areas, being demand studies a crucial factor in the development of sustainable management plans.

\section{Literature Review}

Tourism comprises a set of economically important activities in the world to generate businesses that stimulate local economic movement and thereby find benefits that contribute to the place's development and its inhabitants' quality of life (Aliman et al., 2014; Hartwell et al., 2016). However, people involved in tourism and the society must be aware of this responsibility to assure good practices towards the environment and the preservation of the tourist heritage (Buckley, 2018; Hernández et al., 2017; Thapa \& Lee, 2017). Several authors consider that although environmental knowledge is one-dimensional, it must be segmented into two constructs based on the amount of objective (real) and subjective (perceived) knowledge concerning the environmental conditions of protected areas (Bamberg \& Möser, 2007). Thus, environmental responsibility in tourism refers to responsible travel, which is especially carried out towards some natural protected conservation areas (Wolf et al., 2017). Recent studies have researched the ecotourism potential and zoning, nature protection and sustainable tourism interaction as well as residents' perceptions towards protected areas and ecotourism (Balist et al., 2019; Carvache-Franco et al., 2018; Carvache-Franco et al., 2020; Jojić et al., 2018; Šiljeg et al., 2019; Stojanović et al., 2018).

In recent decades, the demand and popularity of nature-related tourism has led to various forms of tourism, including ecotourism, green tourism or nature tourism. They stand out for being associated with recreational activities that contribute to a healthier life, challenging several sites to maintain the sustainability of resources, as well as to optimize the experience, grant value and satisfy their visitors (Thapa \& Lee, 2017). Thus, all the elements that participate in the configuration of positive experiences for tourists influence cognition and affection, contributing to the increase in value. It means that if the factors that allow the tourist and environment interaction satisfaction are combined, the value in the experience increases (Fiore \& Kim, 2007).

In the marketing literature, the concept of perceived value has been widely used to analyze and un- 
derstand the future behavior of tourists concerning purchasing decisions (Jamal \& Sharifuddin, 2015). In tourism literature, perceived value is commonly conceptualized as the personal evaluation of travel products such as quality service, price, emotions, and social factors (Chiu et al., 2014). The concept of perceived value is closely related to consumer behavior and is a predictor of behavioral intentions (Cronin et al., 2000; $\mathrm{Oh}, 2000)$. In this way, the measurement of perceived value can have far-reaching implications for the field of tourism (Petrick, 2002).

The perceived value can be understood as a construct made by the differences between the benefits received (economic, social and relationships) and sacrifices made (price, time, effort, risk, and convenience) by the consumer (Cronin et al., 2000; Grewal et al., 1998). From this perspective, perceived value is recognized as a multidimensional concept, which involves individual evaluations of the benefits obtained in the travel experience, compared with the sacrifices made, and conditioned by aspects of a rational, affective, and social nature (Chiu et al., 2014). Due to this, the perceived value is subordinated to the judgments of the tourist, whose evaluation is grounded on the pre-purchase information, the quality of the services, the tourist resources, the surrounding nature, the time, money and effort invested, among other aspects (Jamal \& Sharifuddin, 2015). These conceptions of value are based mainly on a utilitarian perspective that involves economic (cognitive) and affective (emotional) assessments, that is, it is between the costs and benefits received and that can be measured after the experience (Oliver, 1997, p. 394; Sánchez-Fernández \& Iniesta-Bonillo, 2009).

Williams and Soutar (2009), in a study in Australia, found five dimensions of perceived value (functional value, value for money, emotional value, social value, and novelty value) in their adventure tourism study, concluding that all dimensions significantly influenced tourist satisfaction. In another research conducted in Malaysia, Jamal et al. (2011) established five dimensions of perceived value: functional value (establishment), functional value (price), experimental value (host-guest interaction), experiential value (activity, culture, and knowledge), and emotional value. Other studies involve the functional, affective, and social dimensions, which affect the general evaluation of the tourists' experience, and, in turn, result in a comparison between the benefits obtained and the costs assumed (Bajs, 2015; Solís-Radilla et al., 2016). In this perspective, some authors recognize social interaction as an important dimension of the quality of the experience and a determining factor of the perceived value, since it can significantly affect the dimensions of value during the intercultural exchange between local people and tourists, participating in the development of knowledge of tourists who learn something different from those exposed in their usual environment (Chiu et al., 2014; Rasoolimanesh et al., 2016; Zhang et al., 2017).

In this way, Lee et al. (2007) divided the perceived value into functional value, general value, and emotional value, and tested its effects on tourist satisfaction with the tour of the demilitarized zone in South Korea. They found that the three values positively influenced tourist satisfaction. Ha and Jang (2010), in another study, considered the hedonic and utilitarian value in gastronomic experiences in Korean restaurants in the United States. They found that both values were positively related to satisfaction. Lee et al. (2010) established the functional and emotional value when investigating the behaviors of visitors to a festival. Their findings showed that both types of perceived value are positively related to tourist satisfaction.

Similarly, Kim and Park (2017), based on twelve variables, found four dimensions of perceived value: economic, functional, emotional, and social. Through the study, they showed that these values had positive effects on overall satisfaction; also, that general satisfaction and tourist satisfaction were a significant antecedent of destination loyalty. In another research, Kim and Thapa (2018) on Jeju Island in South Korea examined how tourists perceived values (quality, emotional, price, and social), perceived quality, emotional, and social values significantly affected the the satisfaction and flow experience. The flow experience was significantly and positively related to satisfaction, environmentally responsible behaviors, and loyalty to the destination. More current in Ecuador, CarvacheFranco et al. (2019) identified four values: economic, functional and social. They also found that the values that are related to satisfaction and loyalty were functional and emotional.

In the same perspective, Peña et al. (2012) examined the relationships between perceived value, satisfaction, and loyalty in rural tourism in Spain. Those results revealed that the perceived value has a positive effect on tourist satisfaction and loyalty, coinciding with several studies that have established the significant influence of perceived value on the satisfaction of the experience (Chen \& Tsai, 2007; Sun et al., 2013). Likewise, for Castellanos-Verdugo et al. (2016), satisfaction can promote the intentions to return and the willingness of ecotourists to recommend the site to family and friends. Therefore, a greater degree of knowledge about ecotourism in the hands of the visitor will favor a positive perception of the value of the ecotourism site, as well as will bring greater positive attitudes towards ecotourism. It should be 
noted that, in the field of tourism, satisfaction is commonly known as a pre-trip evaluation and post-trip expectations and experiences (Chen \& Chen, 2010). Along these lines, Adam et al. (2019) studied the satisfaction and motivation of ecotourists in Kakum National Park, using the following factors: "educational satisfaction," "social satisfaction," "satisfaction with sanitation" and "satisfaction with relaxation."

In another study in Bali, Jaya (2018) identified that the destination image and the perceived value have a positive and significant effect on customer satisfaction. The perceived value has a higher correlation coefficient value when compared to the target image in customer satisfaction. The perceived values that should be the material of the evaluation are the functional and the emotional value. Within this perspective, the perceived value has been considered as a predictor of travelers' intentions (Eid \& El-Gohary, 2015), which represents good planning strategy for destinations to attract tourists who share common needs and values, offering practical implications for the commercialization of ecotourism experiences (Kim \& Park, 2014). In such circumstances, tourist desti- nations should increase their capacity to attract new tourists, without neglecting the promotion and conservation of lasting relationships with tourists who have already visited them (Bala et al., 2014). Thus, the future behavior assumed by the consumer is a product of the perceived value of each tourist experience (Chiu et al., 2014). Therefore, the perceived value directly influences tourist fidelity (Oliver, 1997; Chen \& Chen, 2010). From this perspective, tourists can have a favorable attitude towards a destination and express their intention to revisit and recommend it. Several researchers have incorporated the concept of consumer loyalty to tourism (Baloglu, 2001; Iwasaki \& Havitz, 1998; Yoon \& Uysal, 2005). In loyalty, there can be several criteria. For example, in their study about Galapagos (Ecuador), Rivera and Croes (2010) suggested that ecotourists probably would not return, but they would recommend the destination. Previous studies have shown that perceived value leads to favorable results such as satisfaction and behavioral intentions (Chua et al., 2015; Kim et al., 2015). That is why our study tries to find the relationship between perceived value and other variables as satisfaction and loyalty.

\section{Study area}

Costa Rica is a world-renowned country for its ecological wealth. In 2018, Costa Rica had a total of 2,314, 888 tourist arrivals. (Costa Rican Institute of Tourism ICT, 2020). Ecoutourism experiences stand out since more than $90 \%$ of tourists visit national parks and protected reserves, which cover $20 \%$ of the national territo- ry (Conservation System of Protected Areas of Costa Rica SINAC, 2019). In Costa Rica, approximately $75 \%$ of tourist visits are for vacation. Among the main reasons for visiting the country, the second reason is ecotourism with approximately $64 \%$ of visits (Costa Rican Institute of Tourism ICT, 2020). Hence, ecoutorism is

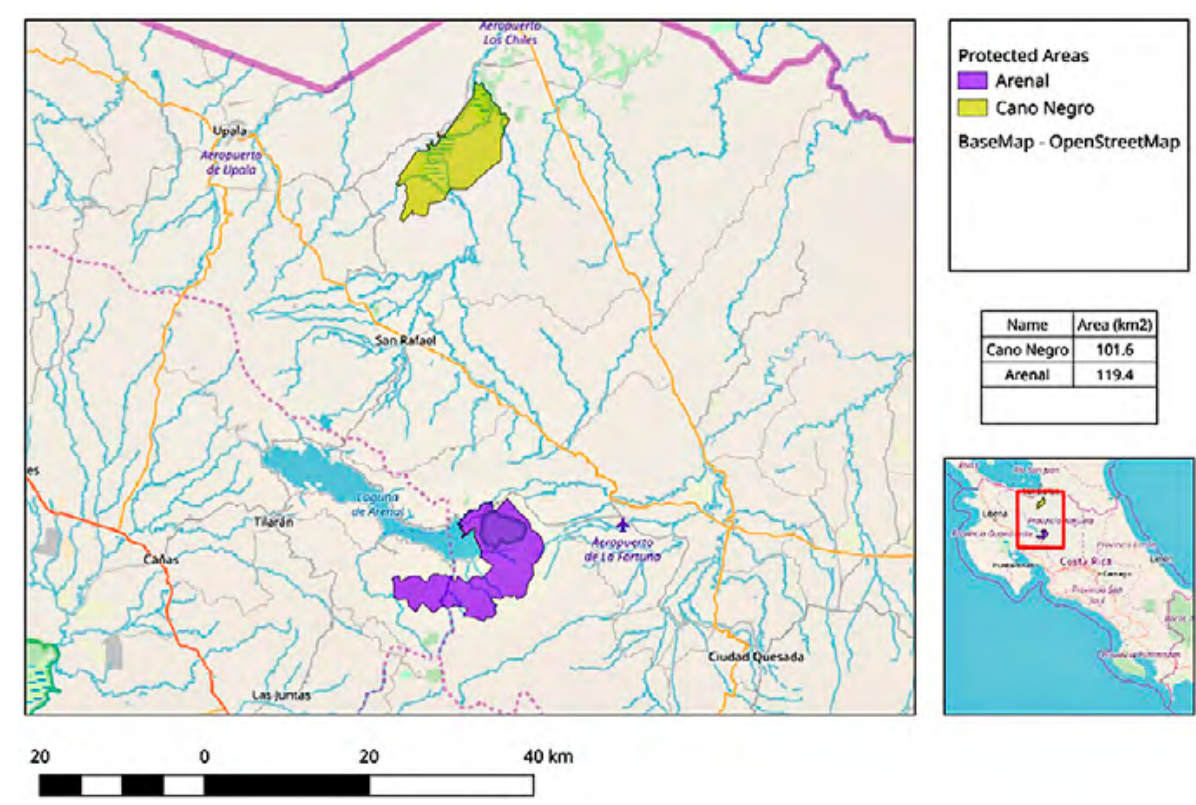

Figure 1. The geographic location of protected areas: Arenal Volcano National Park and Caño Negro Mixed National Wildlife Refuge (Costa Rica).

Source: www.idehn.tec.ac.cr 


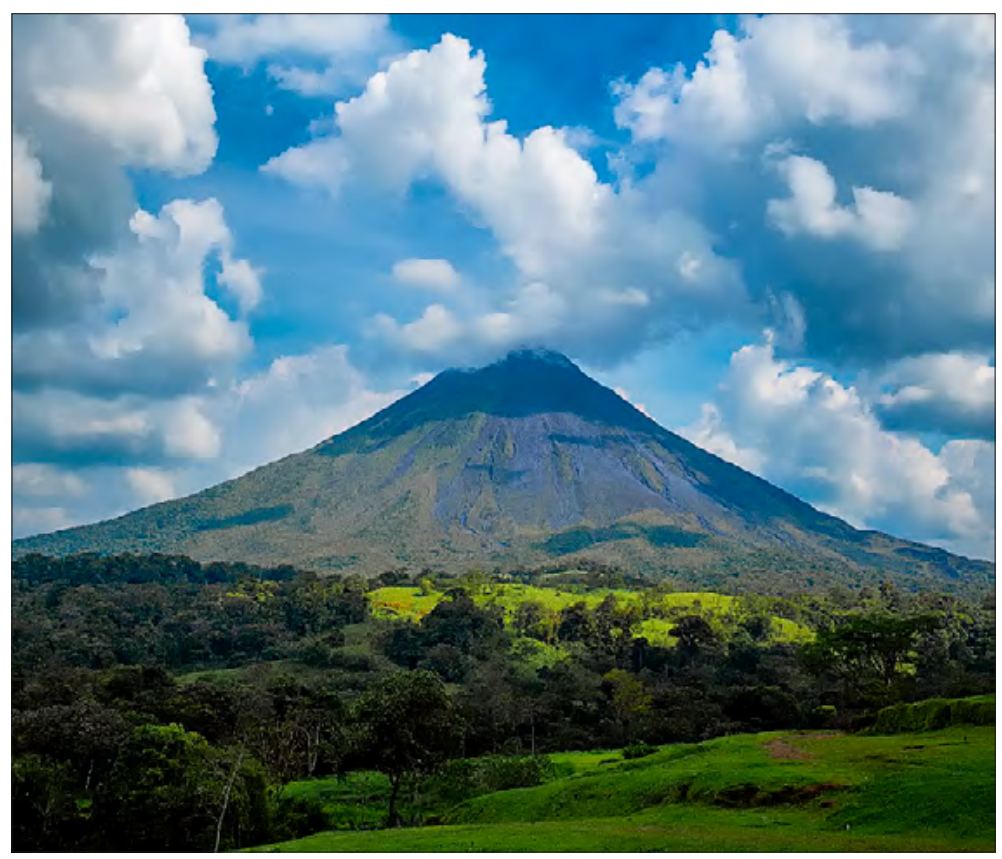

Figure 2. Arenal National Park

Source: Jonathan Serrano Hernández

relevant in Costa Rica. Costa Rica has two protected areas widely visited by domestic and foreign tourists, ideal for ecotourism: The "Arenal National Park" and the "Caño Negro National Wildlife Refuge." (Figure 1).

The "Arenal National Park" with its natural icon the "Arenal Volcano," a colossus that began its activity in 1968 , is one of the most visited parks nationally. It has a territorial extension of 12,010 hectares and houses a unique natural wealth. It has been considered a living laboratory in which geomorphological richness and the complexity of development in biological processes are highlighted. This Costa Rican Nation- al Park received 111,286 tourists in 2018 (Costa Rican Institute of Tourism ICT, 2018). The park was famous for the lava flows that made it shine for many years, despite its activity ceded in 1992. However, it remains one of the nationally protected areas with more geological and geomorphological wealth since it houses both pioneer vegetation and a primary forest. It is a protected area of great richness and attractive for the Performance of research studies and natural observation. (Figure 2, 3).

Costa Rican natural wealth also includes "Caño Negro National Wildlife Refuge," with an area of 9,969

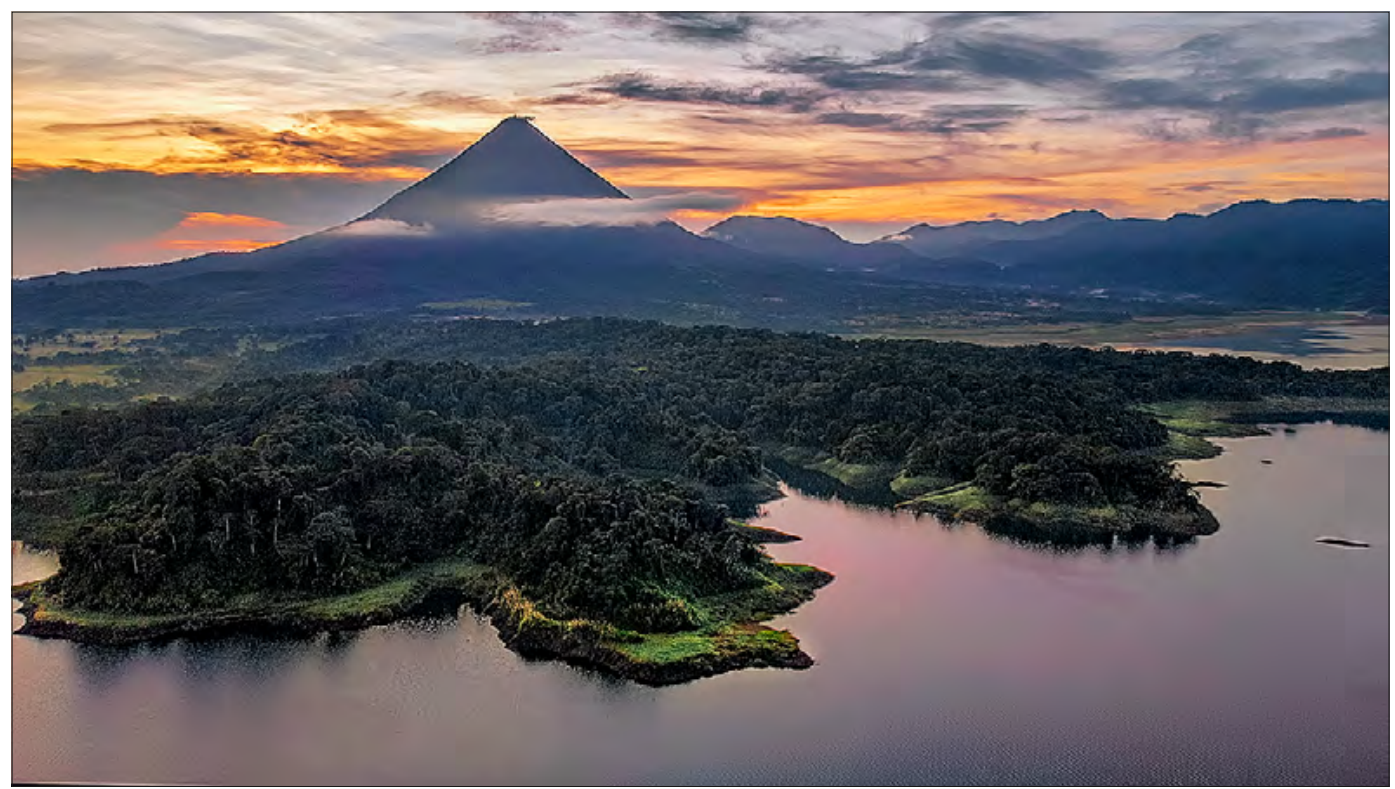

Figure 3. Arenal National Park

Source: Jonathan Serrano Hernández 


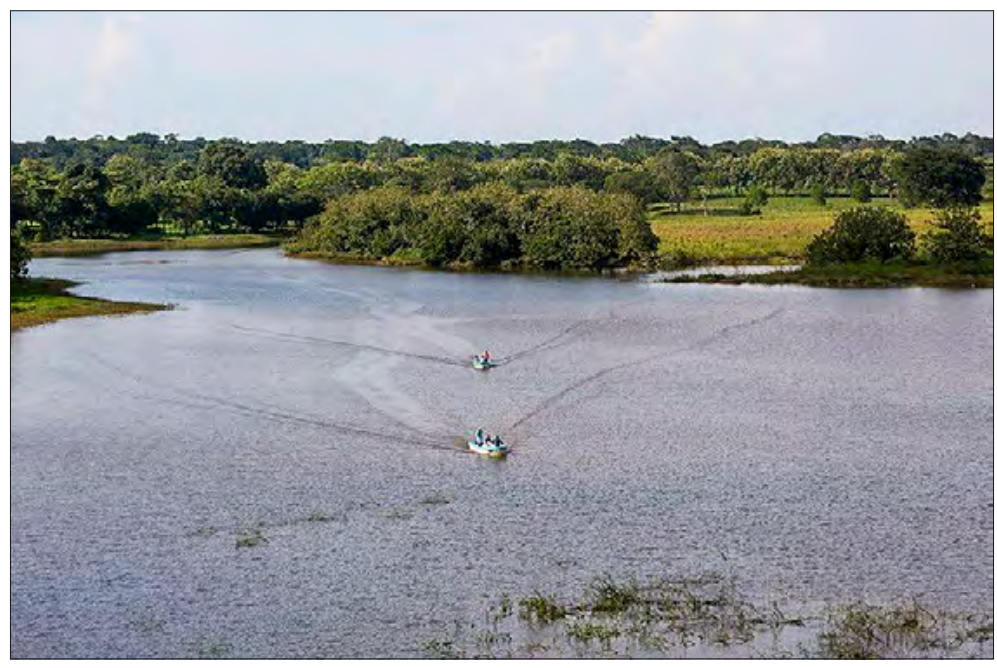

Figure 4. Caño Negro National Wildlife Refuge Source: Moises Brenes Arias

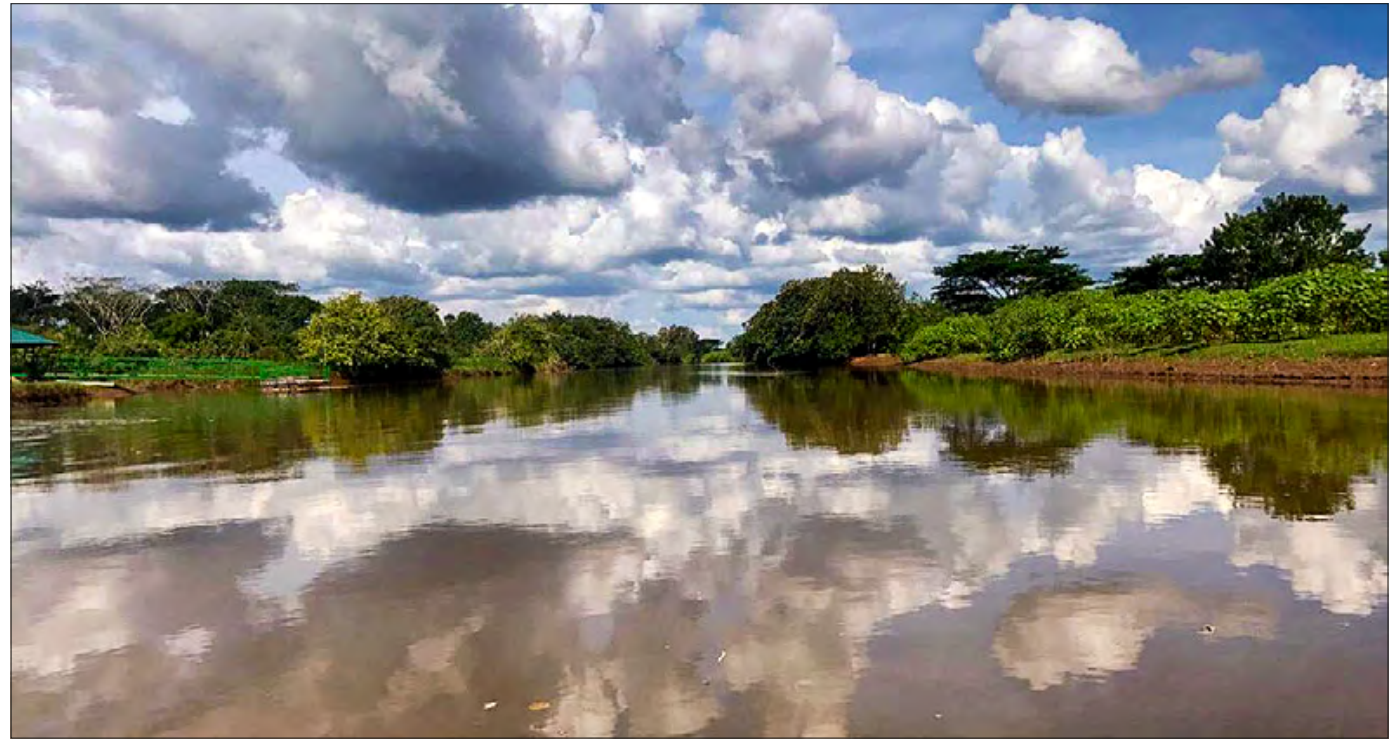

Figure 5. Caño Negro National Wildlife Refuge Source: Moises Brenes Arias

hectares. This refuge shelters migratory birds and endemic freshwater fish, many of these endangered species. Its main attraction is a lagoon and a wetland of more than 880 hectares, which can be crossed in canoes or boats. This protected area constitutes a habitat for many migratory birds and endangered fish, as well as plants, mammals, and reptiles such as the alli- gator. That is why it was cataloged as the third most important wetland worldwide by The Ramsar Wetlands Convention. The intergovernmental treaty that offers the framework for the conservation and rational use of wetlands and their resources worldwide. Also, it has been recognized as a sanctuary and named since 1991, "Wetland of International Importance". (Figure 4,5).

\section{Methodology}

The sample was obtained from national and foreign tourists who were visiting the Arenal National Park and the Caño Negro National Wildlife Refuge in Costa Rica. Tourists were over 18 years of age. The method of simple random sampling was used to provide all the visitors within the protected area with the same probability of being chosen.
A three-section questionnaire was developed to achieve the objective of the present study. The first section dealt with the sociodemographic information of the respondents. It consisted of questions related to origin, gender, age, marital status, education, professional activity and in the company of those who travel with tourists. The second measured the perceived value 
through 12 items, which were related to previous findings on economic, functional, social and emotional values. Thus, for perceived value, the items used by Kim and Park (2017) were adapted. The question of perceived value was measured using a 5-point liker scale where 1 meant "strongly disagreed" and 5 "strongly agreed." The Cronbach's Alpha reliability index reached a value of 0.94 , which indicates a robust index for the scale of the perceived value of the present study.

The third part analyzed the satisfaction and loyalty of tourists. The general satisfaction question was measured through a 5-point likert scale, where 1 was "not at all satisfied" and 5 was "very satisfied." The loyalty questions were measured through a 5-point Likert scale, where 1 was "Strongly disagree" and 5 was "totally agree." Loyalty questions inquired about return, recommendation, and saying positive things about protected areas.The instrument was designed based on several previous studies of perceived value and its relation to satisfaction and loyalty.

The surveys were administered during March and April 2019 to visitors who were within the protected natural areas while resting or performing recreational activities. The sample was collected by a student from the Costa Rica Institute of Technology, who was attentive to clarify the doubts or concerns of the visitors while they were answering the questionnaire autonomously.

The population variability was estimated at $50 \%$ (p $=\mathrm{q}=0.5) .310$ valid surveys were obtained, this being the sample size, with a margin of error of $+/-5.56 \%$ and a confidence level of $95 \%$. The data collected was organized, tabulated, and statistically analyzed using the SPSS 22.0 program for Windows. The data were analyzed in two stages: first, a factorial analysis was carried out to identify the constructs that underlie the variables, providing an overview of the most important perceived values using these constructs. Specifically, a Varimax rotation was used to facilitate the interpretation of the data. The Kaiser criterion was used to find the number of factors, where only factors with eigenvalues greater than 1 were used. The KMO index (Kaiser-Meyer-Olkin) and Bartlett's Sphericity Test were used to determine if it was appropriate perform the factor analysis. In the second stage, Spearman's correlation technique was used to know the dimensions correlated with general satisfaction. Besides, the stepwise multiple regression method was carried out to select the dimensions of the perceived value predicted by future behavior variables.

Table 1. Research file

\begin{tabular}{|l|l|}
\hline Geographic area & $\begin{array}{l}\text { Arenal National Park and the Caño } \\
\text { Negro National Wildlife Refuge } \\
\text { (Costa Rica) }\end{array}$ \\
\hline Population & National and foreign visitors \\
\hline Date of completion & January to May 2019 \\
\hline Process & Simple random sampling \\
\hline Confidence level & $95 \%$ \\
\hline Error range & $+/-5.56 \%$ \\
\hline Valid questionnaires & 310 \\
\hline
\end{tabular}

\section{Results}

The sample was taken from two protected areas of Costa Rica, where $79.4 \%$ were foreign tourists, and $20.6 \%$ were nationals. Regarding gender, $54.8 \%$ were men and $45.2 \%$ women. Its origin was mainly from Europe (36.8\%) and North America (32.3\%). The majority age group was between 21 and 30 years old, with $38.7 \%$, followed by the group between 31 and 40 years old, with $21.3 \%$. The majority were single (51.3\%), followed by the married group (36.1\%). About the level of education, the group of university students was the largest (46.2\%). Regarding their professional activity, the group of private professionals had $27.4 \%$. The majority traveled with the family (35.8\%), followed by those traveling as a couple (29.7\%). (Table 2 ).

\section{Dimensions of perceived value (Factor analysis)}

The factor analysis allowed extracting three dimensions of the perceived value. The principal component analysis was used as a technique for factor extraction. The Varimax rotation method was implement- ed to obtain a clearer interpretation of the factors so that each had very high or low factor loads. The factors taken into account in the Kaiser criteria had own values greater than 1.00. Three factors were part of the solution and represented $80.57 \%$ of the total variance. The KMO index (Kaiser-Meyer-Olkin) was 0.92, so it was excellent for factor analysis. Besides, Barlett's Sphericity Test was significant $<0.05$, so factor analysis was appropiate to apply. Table 3 shows these results.

According to the results of Table 3, the factors had a Cronbach's alpha coefficient between 0.892 and 0.918. Thus, each factor had high reliability, and this indicated that the variables of each factor measured the same construct and were highly correlated with each other. The primary factor was called "economic and functional" and is the factor with the greatest explanatory capacity $(61.32 \%)$ of the total variance. This first dimension was related to the variables of perceived value: the service has good prices, the service has good value for money, the service is afford- 
The Perceived Value in Ecotourism Related to Satisfaction and Loyalty:

a Study from Costa Rica

Table 2. Sociodemographic aspects and characteristics of the trip

\begin{tabular}{|c|c|c|c|}
\hline Demographics & Categories & $N=310$ & $\%$ \\
\hline \multirow{2}{*}{ Origin } & Domestic & 64 & 20.6 \\
\hline & Foreign & 246 & 79.4 \\
\hline \multirow{5}{*}{$\begin{array}{l}\text { Origin by } \\
\text { continent }\end{array}$} & North America & 100 & 32.3 \\
\hline & Europe & 114 & 36.8 \\
\hline & South America & 14 & 4.5 \\
\hline & Asia & 12 & 3.9 \\
\hline & Rest of the world & 70 & 22.6 \\
\hline \multirow{2}{*}{ Gender } & Male & 140 & 45.2 \\
\hline & Female & 170 & 54.8 \\
\hline \multirow{6}{*}{ Age } & Less than20 years old & 40 & 12.9 \\
\hline & 21 - 30 years old & 120 & 38.7 \\
\hline & 31 - 40 years old & 66 & 21.3 \\
\hline & 41 - 50 years old & 41 & 13.2 \\
\hline & 51 - 60 years old & 35 & 11.3 \\
\hline & More than 60 years old & 8 & 2.6 \\
\hline \multirow{3}{*}{ Marital status } & Single & 159 & 51.3 \\
\hline & Married & 112 & 36.1 \\
\hline & Other & 39 & 12.6 \\
\hline \multirow{4}{*}{ Education } & Elementary & 12 & 3.9 \\
\hline & High School & 67 & 21.6 \\
\hline & University & 143 & 46.2 \\
\hline & $\begin{array}{l}\text { Postgraduate/Master/ } \\
\text { Ph.D. }\end{array}$ & 88 & 28.4 \\
\hline \multirow{8}{*}{ Occupation } & Student & 60 & 19.4 \\
\hline & Researcher / scientist & 10 & 3.2 \\
\hline & Businessman & 50 & 16.1 \\
\hline & Private Employee & 85 & 27.4 \\
\hline & Public Employee & 57 & 18.4 \\
\hline & Retired & 7 & 2.3 \\
\hline & Unemployed & 10 & 3.2 \\
\hline & Other & 31 & 10.0 \\
\hline \multirow{5}{*}{$\begin{array}{l}\text { With / without } \\
\text { companion }\end{array}$} & Alone & 10 & 3.2 \\
\hline & Relatives & 111 & 35.8 \\
\hline & Friends & 81 & 26.1 \\
\hline & Apartner & 92 & 29.7 \\
\hline & Other & 16 & 5.1 \\
\hline
\end{tabular}

able, the service has an acceptable quality level, and the service is well organized. The second factor was "emotional" and met $10.63 \%$ of the total variance. This second dimension was related to the following variables: this visit makes me feel happy, I have positive feelings towards it, this visit is pleasant, and the service is convenient for me. The third factor is called "social" and comprised $8.62 \%$ of the total variance. This third dimension was related to the variables of perceived value: I feel like a special person, I make a
Table 3. Dimensions of perceived value (Factor Analysis)

\begin{tabular}{|c|c|c|c|c|}
\hline \multirow{2}{*}{ Variables } & \multicolumn{3}{|c|}{ Components } & \multirow{2}{*}{ Factors } \\
\hline & 1 & 2 & 3 & \\
\hline Good regarding price & 0.851 & & & $\begin{array}{l}\text { Economic- } \\
\text { functional }\end{array}$ \\
\hline Value for money & 0.844 & & & \\
\hline Service is affordable & 0.794 & & & \\
\hline $\begin{array}{l}\text { Acceptable quality } \\
\text { standard }\end{array}$ & 0.748 & & & \\
\hline Well organized & 0.599 & & & \\
\hline Makes me feel happy & & 0.903 & & Emotional \\
\hline Positive feeling & & 0.885 & & \\
\hline Enjoyable & & 0.791 & & \\
\hline Convenient for me & & 0.539 & & \\
\hline $\begin{array}{l}\text { I feel like a special } \\
\text { person }\end{array}$ & & & 0.852 & Social \\
\hline $\begin{array}{l}\text { I make a good } \\
\text { impression on other } \\
\text { people }\end{array}$ & & & 0.811 & \\
\hline $\begin{array}{l}\text { I gain social approval } \\
\text { from others }\end{array}$ & & & 0.785 & \\
\hline Eigenvalues & 7.36 & 1.28 & 1.03 & \\
\hline $\begin{array}{l}\text { Variance explained } \\
(\%)\end{array}$ & 61.32 & 10.63 & 8.62 & \\
\hline Cronbach's Alpha & 0.918 & 0.907 & 0.892 & \\
\hline KMO & 0.92 & & & \\
\hline $\begin{array}{l}\text { Barlett's sphericity } \\
\text { test }\end{array}$ & Chi squ & $\begin{array}{l}\text { ared }=3 \\
\text { sig }=0.0\end{array}$ & 345.69 & \\
\hline
\end{tabular}

Extraction method: Principal component analysis Rotation method: Varimax with Kaiser

good impression on other people, and I get the social approval of others.

\section{Satisfaction and future behavior variables}

The 5-point Likert scale ( 1 being little and 5 a lot) was used to analyze satisfaction and future behavior variables (Table 4).

Table 4. Variables of satisfaction and future behavior

\begin{tabular}{|l|c|c|c|c|}
\hline Variables & Mean & Min. & Max. & $\begin{array}{c}\text { Stand. } \\
\text { Dev }\end{array}$ \\
\hline Overall satisfaction & 4.36 & 1 & 5 & 0.803 \\
\hline $\begin{array}{l}\text { I have the intention to } \\
\text { revisit this protected } \\
\text { area }\end{array}$ & 3.72 & 1 & 5 & 1.324 \\
\hline $\begin{array}{l}\text { I have the intention } \\
\text { to recommend this } \\
\text { protected area }\end{array}$ & 4.32 & 1 & 5 & 0.947 \\
\hline $\begin{array}{l}\text { When I talk about } \\
\text { this protected area, } \\
\text { I will give positive } \\
\text { comments }\end{array}$ & 4.42 & 1 & 5 & 0.847 \\
\hline
\end{tabular}


According to the results of Table 4, overall satisfaction reached a high level of 4.36 (higher than 4), so tourists were very satisfied in these protected areas. Concerning the variables of future behavior, the intentions of coming back to these protected areas reached a value of 3.72 , so the perceived value of the services in these destinations should be improved. On the other hand, tourists had a high level of 4.32 concerning the intentions of recommending these protected areas. Also, tourists had a high level of 4.42 in intentions of saying positive things about these destinations.

\section{Relationship between perceived value and satisfaction}

Spearman's correlation coefficient has been used to analyze the relationship between perceived value and overall satisfaction. This coefficient was chosen because it was the most suitable for the analysis of ordinal or scale variables. Table 5 shows the results.

Table 5. Relationship between perceived value and overall satisfaction (Spearman correlation)

\begin{tabular}{|l|c|}
\hline Factors & Correlation \\
\hline Economic and functional & $0.437^{* *}$ \\
\hline Emotional & $0.422^{* *}$ \\
\hline Social & $0.252^{* *}$ \\
\hline
\end{tabular}

**The correlation is significant at the 0.01 level

As presented in Table 5, all dimensions of perceived value were significantly and positively related to overall satisfaction, so there is a significant relationship between perceived value and overall satisfaction, coinciding with several studies (Carvache-Franco et al., 2019; Jaya, 2018; Lee et al., 2007; Lee et al., 2010; Peña et al., 2012; Sun et al., 2013). The economic and functional dimension was the one most related to overall satisfaction, so prices and the quality of services should improve to increase the satisfaction of tourists in these destinations. The second dimension that was related to general satisfaction was the emotional dimension, which means that the emotion felt by tourists in these destinations needs to be improved to increase their overall satisfaction in these protected areas.

\section{Relationship between perceived value and intentions to return to protected areas}

For this case, the stepwise multiple regression method was used, which was appropriate to estimate or predict future behavior (return). A correlation coefficient was no longer used to find the relationship between perceived value and return intentions, because return is a future behavioral variable. Table 6 shows the results.

In Table 6, the R-square had a value of 0.28 , so it was an adequate value, since the future behavior of tourists has been little predictable. However, the $\mathrm{p}$ value of the F test was significant $(\mathrm{p}<0.01)$, which indicated a real relationship between the significant predictors (perceived value) and the response variable (return intentions). Therefore, the model was adequate.The "emotional" dimension was the most significant predictor of tourists' intentions to revisit these protected areas (Beta $=0.331, \mathrm{p}<0.01)$. The second most significant element was the "social" (Beta $=0.301, \mathrm{p}<0.01)$.

\section{The perceived value and intentions of recommending protected areas}

The stepwise multiple regression method was used to analyze the dimensions of perceived value that predict the intentions of recommending these protected areas. Table 7 shows the results.

According to Table 7, the $\mathrm{R}$ squared had a value of 0.48 , so it was an adequate value for the analysis of future behavior. Furthermore, the $\mathrm{p}$ value of the $\mathrm{F}$ test was significant $(\mathrm{p}<\mathrm{0.01})$, so there was a signif-

Table 6. Relationship between perceived value and intentions to return to protected areas (Regression)

\begin{tabular}{|l|c|c|c|c|c|c|}
\hline Factors & Beta & t & Sig. & $\mathbf{R}^{2}$ & F & Sig. \\
\hline Emotional & 0.331 & 6.797 & 0.000 & 0.280 & 39,305 & 0.000 \\
\hline Social & 0.301 & 6.181 & 0.000 & & & \\
\hline Economic and functional & 0.287 & 5.897 & 0.000 & & & \\
\hline (Constant) & & 57.490 & 0.000 & & & \\
\hline
\end{tabular}

Table 7. Relationship between perceived value and intentions to recommend protected areas (Regression)

\begin{tabular}{|l|c|c|c|c|c|c|}
\hline Factors & Beta & $\mathrm{t}$ & Sig. & $\mathrm{R}^{2}$ & $\mathrm{~F}$ & Sig. \\
\hline Emotional & 0.542 & 13.104 & 0.000 & 0.480 & 93,590 & 0.000 \\
\hline Economic and functional & 0.371 & 8.977 & 0.000 & & & \\
\hline Social & 0.221 & 5.337 & 0.000 & & & \\
\hline (Constant) & & 110.137 & 0.000 & & & \\
\hline
\end{tabular}


icant relationship between the perceived value and the intention to return. Therefore, the model was adequate.The "emotional" dimension was the most significant predictor of tourists' intentions to recommend these protected areas $($ Beta $=0.542, p<0.01)$. The second most significant element was the "economic and functional" (Beta $=0.371, \mathrm{p}<0.01)$. However, it is not a predictor as important as the emotional factor.

\section{The perceived value and saying positive things about the ecotourism destination}

The stepwise multiple regression method was used to analyze the dimensions of perceived value that predict the intentions of saying positive things about these protected areas. Table 8 presents the results.

In Table 8, the researchers found an $\mathrm{R}$ squared value of 0.50 that was appropriate for analyzing future behavios. Also, the model was adequate because the F test was significant $(p(p<0.01)$, and there was a significant relationship between the perceived value and the intention to return. Therefore, the model was adequate. The most significant predictor of tourists' intentions to provide positive feedback about the protected areas was the "Emotional" dimension (Beta = $0.569, \mathrm{p}<0.01)$. The "economic and functional" (Beta $=$ $0.370, p<0.01$ was the most significant element. However, the latter is not a relevant predictor.

Table 8. Relationship between the dimensions of perceived value and saying positive things about the ecotourism destination (Regression)

\begin{tabular}{|l|l|l|l|l|l|l|}
\hline Factors & Beta & t & Sig. & $\mathbf{R}^{2}$ & F & Sig. \\
\hline Emotional & 0.569 & 14.058 & 0.000 & 0.503 & 102,399 & 0.000 \\
\hline Economic and functional & 0.370 & 9.140 & 0.000 & & & \\
\hline Social & 0.206 & 5.102 & 0.000 & & & \\
\hline (Constant) & & 129.024 & 0.000 & & & \\
\hline
\end{tabular}

\section{Discussion}

This study sought to establish the dimensions of perceived value and their relationship with ecotourists' satisfaction and loyalty. Thus, three dimensions of perceived value in ecotourism have been found: economic-functional value, emotional value, and social value. When comparing these results with other previous findings, we discovered similarities, as in the paper of Lee et al. (2007), who found general, functional, and emotional values, being the last two related to our economic-functional and emotional values. In another research, Williams and Soutar (2009) identified five dimensions of perceived value: functional value, value for money, emotional value, social value, and novelty value, which are comparable to our economic-functional, emotional, and social values, respectively. Moreover, Lee et al. (2010) discovered the functional and emotional values, similar to our economic-functional and emotional values, but they did not find the social value as in the current paper.

Another investigation is that of Jamal et al. (2011), who identified five dimensions of perceived value: first, functional value (establishment), and functional value (price) were both similar to our economic-functional value. He also found the experimental value (hostguest interaction) and the experiential value (activity, culture, and knowledge) comparable to our social value. Finally, his emotional value was also very similar to our emotional value. In the same perspective, Bags (2015) and Solís-Radilla et al. (2016) found function- al, affective, and social values, which are similar to our economic-functional, emotional, and social values, respectively. Conversely, Kim and Thapa (2018) discovered quality, emotional, price, and social dimensions as perceived values, being closely related to the economic-functional, emotional, and social values, respectively, that emerged from this research. In more similar studies, Carvache Franco et al. (2019) and Kim and Park (2017) found four perceived values: economic, functional, emotional and social. In our investigation we found the same values (economic-functional, emotional and social) with the exception that the economic-functional value was found together, which contributes to the literature in this field, since it is possible in an ecotourism destination to find these four perceived values, but the economic and the functional values can also be seen as a single dimension, having its own characteristics, so it should not be studied separately.

Regarding the perceived value and its relation to general satisfaction, our results have found that all the dimensions of the perceived value were significantly and positively related to general satisfaction. Similar results were found in other studies (Carvache-Franco et al, 2019; Jaya, 2018; Lee et al., 2007; Lee et al., 2010; Peña et al., 2012; Sun et al., 2013), which indicates that all dimensions of perceived value are related to overall satisfaction.

Concerning the influence of the main dimensions of perceived value with general satisfaction, Kim and 
Park (2017) found the functional, social, and emotional dimensions, related to those found by us. In another study, Kim and Thapa (2018) established the emotional and social dimensions in satisfaction, similar to our second motivation, "emotional value." Also, for Jaya (2018), the perceived values that should be the material of the evaluation were the functional and the emotional values, comparable to our economic-functional and emotional results. For Carvache-Franco et al. (2019), functional and emotional values were linked to satisfaction and loyalty, results that are closely related to ours (economic-functional and emotional values). The findings of this study contribute to the literature by establishing that the main perceived values related to general satisfaction are the "functional-economic value" and the "emotional value."

Regarding loyalty, several studies have found that perceived value influences the intention of returning to a destination (Chen \& Chen, 2010; Oliver, 1997; Peña et al., 2012). However, it has not been found which dimension most influences the intentions of returning to an ecotourism destination. Our study contributes to the literature as it is the first to analyze the dimensions of perceived value that are the most important for sat- isfaction and loyalty in ecotourism. Few studies have been found that analyze whether there is a relationship between perceived value with satisfaction and loyalty. However, none of them has focused on analyzing the dimensions of perceived value that highly influence or affect satisfaction and loyalty in ecotourism.

As a contribution to the literature, the findings of this study showed that the dimension of "emotional value" was the most significant predictor of tourists' intentions to revisit, recommend and say positive things about these protected areas. Therefore, the "emotional" value is the main predictor of loyalty in ecotourism, this being the greatest contribution of this study to the literature in this field. This relevant contribution to the literature encourages the study of emotional value as the main predictor of loyalty. Thus, our research deepens the understanding of emotions and their relationship with the loyalty of tourists. In practice, by knowing the importance of emotional value for loyalty in ecotourism, tourism entreprises can improve the supply of activities related to emotional value, which bring new experiences or adventures to tourists. These type of activities would increase the loyalty of tourists in ecotourism.

\section{Conclusions}

Ecotourism is a type of tourism where visitors have the opportunity to carry out activities related to nature, culture, and community in a destination, respecting the environment. Protected areas are one of the main destinations visited for ecotourism because of their rich flora and fauna and where activities can be carried out in contact with nature. In this regard, it is important to conduct demand studies in these destinations to contribute with guidelines for the elaboration of public policies and the execution of sustainable programs within the protected areas.

Studying the perceived value in ecotourism is crucial to generalize results and contribute to the literature on this subject. In this way, three dimensions were found in the value perceived in ecotourism destinations. The most important being "economic and functional value," followed by "emotional value" and "social value." The "economic and functional" and "emotional" dimensions have the greatest influence on overall satisfaction. The "emotional" and "social" dimensions are the most significant predictors of tourists' intentions to return to these ecotourism destinations. En cambio, The "emotional" dimension was the most significant predictor of tourists' intentions to recommend and say positive things about this ecotourism destination.

Among the theoretical implications, previous literature has found four perceived values in ecotour- ism: economic, functional, emotional and social (Carvache Franco et al., 2019; Kim \& Thapa, 2018; Kim and Park, 2017, Lee et al., 2007; Lee et al., 2010, Solís-Radilla et al., 2016; Williams \& Soutar, 2009). But as seen in this research, the economic and functional value can be merged into a single dimension called "economic and functional" value. Regarding the relationship of perceived value with general satisfaction, the findings show that all dimensions of perceived value are related to general satisfaction, as previous studies have also shown (Carvache-Franco et al., 2019; Jaya, 2018; Lee et al., 2007; Lee et al., 2010; Peña et al., 2012; Sun et al., 2013). The main perceived values that are related to overall satisfaction are "functional-economic value" and "emotional value," closely related to the results reported in other studies (Kim and Park, 2017; Kim and Thapa, 2018; Jaya, 2018; Carvache- Franco et al., 2019). The emotional value is the main predictor of loyalty in ecotourism, representing the major contribution of this study to the literature.

Among the practical implications derived from this research, the perceived value helps tourism-related companies know the significance that tourists grant to services, according to its different dimensions. Therefore, protected area managers must improve emotional valueby offering innovative activities that really excite touristsand bring new experiences or ad- 
ventures. Hence, tourists will feel memorable enjoyment. In addition, social interaction is an opportunity for meetingpeople with similar interests and sharing experiences. It is also vital to consider that the perceived value is a variable that helps companies to set prices and manage the quality of their services. That is why the economic and functional value that tourists perceive from the services provided must be analyzed. With the improvement of the supply considering the perceived value, the satisfaction and loyalty of tourists increases bringing benefits to the destination and the community. Besides, the perceived value also pro- vides information to companies for preparing more efficient action plans, increasing the effectiveness of strategic actions and offering services considering the tourists expectations and values.

Finally, the main limitation of the present study was the temporality of the sample collection as the demand may vary in different seasons. In addition, as the study was carried out in two specific protected areas, soits results are limited to the perceived value of tourists visiting these sites. This research study opens a new line of research concerning the perceived value related to environmental care in an ecotourism destination.

\section{References}

Adam, I., Adongo, C. A., \& Amuquandoh, F. E. (2019). A structural decompositional analysis of eco-visitors' motivations, satisfaction and post-purchase behaviour. Journal of Ecotourism, 18(1), 60-81.

Aliman, N. K., Hashim, S. M., Wahid, S. D. M., \& Harudin, S. (2014). Tourist expectation, perceived quality and destination image: Effects on perceived value and satisfaction of tourists visiting Langkawi Island, Malaysia. Asian Journal of Business and Management, 2(3), 212-222. http://www.ajouronline.com/

Bajs, I. (2015). Tourist perceived value, relationship to satisfaction, and behavioral intentions: the example of the Croatian tourist destination Dubrovnik. Journal of Travel Research, 54(1), 122-134. https://doi. org/10.1177/0047287513513158

Bala, B. M., Nizam, I. H., Dalil, M., \& Kawu, A. (2014). Moderating role of affective destination image on the relationship between tourist's satisfaction and behavioural intention: Evidence from Obudu Mountain Resort. Journal of Environment and Earth Science, 4(4), 47-60.

Balist, J., Heydarzadeh, H., \& Salehi, E. (2019). Modeling, evaluation, and zoning of Marivan county ecotourism potential using fuzzy logic, FAHP, and TOPSIS. Geographica Pannonica, 23(1), 47-63. https://doi.org/10.5937/gp23-18879

Baloglu, S. (2001). An investigation of a loyalty typology and the multidestination loyalty of international travelers. Tourism Analysis, 6(1), 41-52.

Bamberg, S., \& Möser, G. (2007). Twenty years after Hines, Hungerford, and Tomera: A new metaanalysis of psycho-social determinants of pro-environmental behaviour. Journal of Environmental. Psychology, 27(1), 14-25. https://doi.org/10.1016/j.jenvp.2006.12.002

Björk, P. (2007). Definition paradoxes: From concept to definition. In J. Higham (Ed.), Critical issues in ecotourism (pp. 23-45). Burlington, MA: Elsevier.
Briassoulis, H., \& Van Der S., J. (2013). Tourism and the environment: regional, economic, cultural and policy (2nd Ed.). New York, NY: Springer Science \& Business Media.

Buckley, R. (2018). Tourism and natural World Heritage: A complicated relationship. Journal of Travel Research, 57(5) 563-578. https://doi. org/10.1177/0047287517713723

Carvache-Franco, M., Carvache-Franco, O., Carvache-Franco, W., Orden-Mejía, M., \& MacasLópez, C. (2018). Segmentation of coastal marine demand from a national recreational area: Villamil Beach, Ecuador. Geographica Pannonica, 22(4), 276-284. https://doi.org/10.5937/gp22-18410

Carvache-Franco, M., Carvache-Franco, O., Solis-Radilla, M. M., \& Carvache-Franco, W. (2019). The perceived value and profile of protected areas visitors: A case study of the Guayas province, Ecuador. Geographica Pannonica, 23(2), 135-147. https:// doi.org/10.5937/gp23-20582

Carvache-Franco, M., Carvache-Franco, O., Carvache-Franco, W., \& Villagómez-Buele, C. (2020). From Satisfaction in Eco-tourism to Loyalty in a National Park. GeoJournal of Tourism and Geosites, 28 (1), 191-202. https://doi.org/10.30892/ gtg. 28115-462

Castellanos-Verdugo, M., Vega-Vázquez, M., Oviedo-García, M. Á., \& Orgaz-Agüera, F. (2016). The relevance of psychological factors in the ecotourist experience satisfaction through ecotourist site perceived value. Journal of Cleaner Production, 124, 226-235. https://doi.org/10.1016/j.jclepro.2016.02.126

Chen, C.-F., \& Chen, F.-S. (2010). Experience quality, perceived value, satisfaction and behavioral intentions for heritage tourists. Tourism Management, 31(1), 29- 35. https://doi.org/10.1016/j. tourman.2009.02.008

Chen, C.-F., \& Tsai, D. (2007). How destination image and evaluative factors affect behavioral intentions? 
Tourism Management, 28, 1115-1122. doi:10.1016/j. tourman.2006.07.007

Cheng, T. M., \& Wu, H. C. (2015). How do environmental knowledge, environmental sensitivity, and place attachment affect environmentally responsible behavior? An integrated approach for sustainable island tourism. Journal of Sustainable Tourism, 23(4), 557-576. https://doi.org/10.1080/og669582.201 4.965177

Chikuta, O., du Plessis, L., \& Saayman, M. (2017). Nature-based travel motivations for people with disabilities. African Journal of Hospitality, Tourism and Leisure, 6(1), 1-16.

Chiu, Y. T. H., Lee, W. I., \& Chen, T. H. (2014). Environmentally responsible behavior in ecotourism: Exploring the role of destination image and value perception. Asia Pacific Journal of Tourism Research, 19(8), 876-889. https://doi.org/10.1080/10941 $\underline{665.2013 .818048}$

Chiu, Y. T. H., Lee, W. I., \& Chen, T. H. (2014). Environmentally responsible behavior in ecotourism: Antecedents and implications. Tourism management, 40, 321-329. http://dx.doi.org/10.1016/j.tourman.2013.06.013

Chua, B. L., Lee, S., Goh, B., \& Han, H. (2015). Impacts of cruise service quality and price on vacationers' cruise experience: Moderating role of price sensitivity. International Journal of Hospitality Management, 44, 131-145. https://doi.org/10.1016/j.ijhm.2014.10.012

Conservation System of Protected Areas of Costa Rica SINAC. (2019). Protected Wild Areas. http://www. sinac.go.cr/ES/asp/Paginas/default.aspx

Costa Rican Institute of Tourism (2018) Retrieved from https://www.ict.go.cr/es/documentos-institucionales/estad\% $\mathrm{C}_{3} \% \mathrm{ADsticas/cifras-tur \%} \mathrm{C}_{3} \% \mathrm{ADsticas} /$ visita-a-las-\% $\mathrm{C}_{3} \%$ A1reas-silvestres-protegidassinac/1397-2017-2/file.html

Costa Rican Institute of Tourism ICT. (2020). Tourist Figures. https://www.ict.go.cr/es/estadisticas/cifras-turisticas.html

Cronin, J. J. Jr., Brady, M., \& Hult, T. (200o). Assessing the effects of quality, value, and customer satisfaction on consumer behavioral intentions in service environments. Journal of Retailing, 76(2), 193-218. https://doi.org/10.1016/So022-4359(oo)0oo28-2

Eid, R., \& El-Gohary, H. (2015). The role of Islamic religiosity on the relationship between perceived value and tourist satisfaction. Tourism Management, 46, 477-488. https://doi.org/10.1016/j.tourman.2014.08.003

Fiore, A. M., \& Kim, J. (2007). An integrative framework capturing experiential and utilitarian shopping experience. International Journal of Retail and Distribution Management, 35(6), 421-442. https:// doi.org/10.1108/09590550710750313
Grewal, D., Monroe, K., \& Krishnan, R. (1998). The effects of price comparison advertising on buyers' perceptions of acquisition value, transaction value, and behavioral intentions. Journal of Marketing, 62(2), 46-59. doi:10.2307/1252160

Ha, J., \& Jang, S. C. (2010). Perceived values, satisfaction, and behavioral intentions: The role of familiarity in Korean restaurants. International Journal of Hospitality Management, 29(1), 2-13. https://doi. org/10.1016/j. ijhm.2009.03.009

Hartwell, H., Fyatt, A., Page. S. W., Ladkin, A., \& Hemingway, A. (2016). Progress in tourismand destination wellbeing research. Current issues in Tourism, 21(16), 1830-1892. https://doi.org/10.1080/136835 00.2016 .1223609

Hernández, L. J. Á., González M. A., Hernández, T. S., \& Ramón, O. A. A. (2017). The Impact of mass tourism in the Canary Islands in the context of world biosphere reserves. Cuadernos de Turismo, 40, 685688. https://doi.org/10.6018/turismo.40.309751

Honey, M. (2008). Ecotourism and sustainable development: Who owns paradise? (2nd ed.). Washington, DC: Island Press.

Hultman, M., Kazeminia, A., \& Ghasemi, V. (2015). Intention to visit and willingness to pay premium for ecotourism: The impact of attitude, materialism, and motivation. Journal of Business Research, 68(9), 1854-1861. https://doi.org/10.1016/j. jbusres.2015.01.013

Iwasaki, Y., \& Havitz, M. E. (1998). A path analytic model of the relationships between involvement, psychological commitment and loyalty. Journal of Leisure Research, 30(2), 256-280.

Jamal, A., \& Sharifuddin, J. (2015). Perceived value and perceived usefulness of halal labeling: The role of religion and culture. Journal of Business Research, 68(5), 933-941. https://doi.org/10.1016/j.jbusres.2014.09.020

Jamal, S. A., Othman, N. A., \& Muhammad, N. (2011). Tourist perceived value in a communitybased homestay visit: An investigation into the functional and experiential aspect of value. Journal of Vacation Marketing, 17(1), 5-15. https://doi. org $/ 10.1177 \% 2 \mathrm{~F} 1356766710391130$

Jaya, I. P. G. I. T. (2018). Measuring How Destination Image and Perceive Value Affect Customers' Satisfaction for Ecotourism. International Journal of Social Science and Business, 2(2), 68-76. http://dx.doi. org/10.23887/ijssb.v2i2.13987

Jojić, G. T., Brankov, J., \& Miljanović, D. (2018). Residents' perception toward protected areas: Carska Bara Special Nature Reserve (Vojvodina, Serbia). Geographica Pannonica, 22(4), 264-275. https://doi. org/10.5937/gp22-18960

Jones, S. (2005). Community-based ecotourism: The significance of social capital. Annals of Tourism Re- 
search, 32(2), 303-324. https://doi.org/10.1016/j.annals.2004.06.007

Ketema, T. D. (2015). Development of community based ecotourism in Wenchi Crater Lake, Ethiopia: Challenges and prospects. Journal of Hospitality Management and Tourism, 6(4), 39-46. http://www. academicjournals.org/JHMT

Kim, H., Woo, E., \& Uysal, M. (2015). Tourism experience and quality of life among elderly tourists. Tourism Management, 46, 465-476. https://doi. org/10.1016/j.tourman.2014.08.002

Kim, K.-H., \& Park, D.-B. (2014). Factors influencing rural tourists' purchasing behaviour: Four types of direct farm markets in South Korea. Tourism Economics, 20(3), 629-645. https://doi.org/10.5367/ te.2013.0305

Kim, K.-H., \& Park, D.-B. (2017). Relationships among perceived value, satisfaction, and loyalty: community-based ecotourism in Korea. Journal of Travel ¿Tourism Marketing, 34,2, 171-191. https://doi.org/1 0.1080/10548408.2016.1156609

Kim, M., \& Thapa, B. (2018). Perceived value and flow experience: Application in a nature-based tourism context. Journal of destination marketing \& management, 8, 373-384. https://doi.org/10.1016/j. jdmm.2017.08.002

Lee, C.-K., Yoon, Y.-S., \& Lee, S.-K. (2007). Investigating the relationships among perceived value, satisfaction, and recommendations: The case of the Korean DMZ. Tourism Management, 28(1), 204214. doi:10.1016/j. tourman.2005.12.017. https://doi. org/10.1016/j.tourman.2005.12.017

Lee, J. S., Lee, C. K., \& Choi, Y. J. (2010). Examining the role of emotional and functional values in festival evaluation. Journal of Travel Research, 50(6), 658696. https://doi.org/10.1177\%2Foo 47287510385465

Liu, J., Qu, H., Huang, D., Chen, G., Yue, X., Zhao, X., \& Liang, Z. (2014). The role of social capital in encouraging residents' pro-environmental behaviors in community-based ecotourism. Tourism Management, 41, 190-201. https://doi.org/10.1016/j.tourman.2013.08.016

Mostafa, M. M. (2007). A hierarchical analysis of the green consciousness of the Egyptian consumer. Psychology \& Marketing, 24(5), 445-473. https://doi. org/10.1002/mar.20168

Oh, H. (2000). Diners' perceptions of quality, value, and satisfaction: A practical viewpoint. Cornell Hotel and Restaurant Administration Quarterly, 41(3), 58-66. https://doi.org/10.1177/001088040004100317

Oliver, R. L. (1997). Satisfaction: A behavioral perspective on the consumer. New York, NY: McGraw-Hill.

Peña, A. I. P., Jamilena, D. M. F., \& Molina, M. Á. R. (2012). The perceived value of the rural tourism stay and its effect on rural tourist behaviour. Jour- nal of Sustainable Tourism, 20(8), 1045-1065. https:// doi:10.1080/ 09669582.2012.667108

Petrick, J. F. (2002). Development of a multi-dimensional scale for measuring the perceived value of a service. Journal of Leisure Research, 34(2), 119-134. https://doi.org/10.1080/00222216.2002.11949965

Rasoolimanesh, S. M., Dahalan, N., \& Jaafar, M. (2016). Tourists' perceived value and satisfaction in a community-based homestay in the Lenggong Valley World Heritage Site. Journal of Hospitality and Tourism Management, 26, 72-81. https://doi. org/10.1016/j.jhtm.2016.01.005

Reimer, J. K., \& Walter, P. (2013). How do you know it when you see it? Community-based ecotourism in the cardamom mountains of southwestern Cambodia. Tourism Management, 34, 122-132. https:// doi.org/10.1016/j. tourman.2012.04.002

Rivera, M. A., \& Croes, R. (2010). Ecotourists' loyalty: will they tell about the destination or will they return?. Journal of Ecotourism, 9(2), 85-103. https:// doi.org/10.1080/14724040902795964

Sánchez-Fernández, R., \& Iniesta-Bonillo, M. Á. (2009). Efficiency and quality as economic dimensions of perceived value: Conceptualization, measurement, and effect on satisfaction. Journal of Retailing and Consumer Services, 16(6), 425-433. https://doi.org/10.1016/j. jretconser.2009.06.003

Šiljeg, A., Cavrić, B., Šiljeg, S., Marić, I., \& Barada, M. (2019). Land suitability zoning for ecotourism planning and development of Dikgatlhong Dam, Botswana. Geographica Pannonica, 23(2), 76-86. https:// doi.org/10.5937/gp23-20633

Si-Shyun, L. J. (2018). The moderating role of intercultural service encounters in the relationship among tourist's destination image, perceived value and environmentally responsible behaviors. American Journal of Tourism Management, 7(1), 1-9. 1 https:// doi.org/10.5923/j.tourism.20180701.01

Solís-Radilla, M. M., Hernández-Lobato, L., \& Villagómez-Méndez, J. (2016). El valor percibido del destino turístico en relación con el perfil del turista en Acapulco, Guerrero-México. Investigación administrativa, 46(118), 1-28.

Stojanović, V., Lazić, L., \& Dunjić, J. (2018). Nature protection and sustainable tourism interaction in selected Ramsar sites in Vojvodina (Northern Serbia). Geographica Pannonica, 22(3), 201-207. https:// doi.org/10.5937/gp22-16637

Sun, X., Chi, C. G. Q., \& Xu, H. (2013). Developing destination loyalty: The case of Hainan Island. Annals of Tourism Research, 4, 547-577. https://doi. org/10.1016/j.annals.2013.04.006

Tanti, H., \& Raya, A. (2016). Responsible environmental vehavior intention of travelers on ecotour- 
ism sites. Tourism and Hospitality Management, 22(2),135-150. https://doi.org/10.20867/thm.22.2.4

Thapa, B., \& Lee, J. (2017). Visitor experience in Kafue National Park, Zambia. Journal Ecotour, 16(2), 112130. https://doi.org/10.1080/14724049.2016.1245737

Williams, P., \& Soutar, G. (2009). Value, satisfaction and behavioral intentions in an adventure tourism context. Annals of Tourism Research, 36(3), 413-438. https://doi.org/10.1016/j.annals.2009.02.002

Wolf, I. D., Ainsworth, G. B., \& Crowley, J. (2017). Transformative travel as a sustainable market niche for protected areas: a new development, marketing and conservation model. Journal of Sustainable Tourism, 25(11), 1650-1673. https://doi.org/10.1080/o 9669582.2017 .1302454

Wolf, I. D., Ainsworth, G. B., \& Crowley, J. (2017). Transformative travel as a sustainable market niche for protected areas: a new development, marketing and conservation model. Journal of Sustainable Tourism, 25(11), 1650-1673. https://doi.org/10.1080/0 9669582.2017 .1302454

Yoon,Y.S., \& Uysal,M.(2005).Anexaminationoftheeffects of motivation and satisfaction on destination loyalty: A structural model. Tourism Management, 26(1), 45-56. https://doi.org/10.1016/j. tourman.2003.08.016

Zeithaml, V. A. (1988). Consumer perceptions of price, quality, and value: A meansend model and synthesis of evidence. Journal of Marketing, 52(3), 2-22. http://dx.doi.org/10.2307/1251446

Zhang, C. B., Li, Y. N., Wu, B., \& Li, D. J. (2017). How WeChat can retain users: Roles of network externalities, social interaction ties, and perceived values in building continuance intention. Computers in Human Behavior, 69, 284, 293. https://doi. org/10.1016/j.chb.2016.11.069 